\title{
The African traditional religious landscape: An examination of the role of traditional leaders in the fight against HIV and AIDS in Chipinge, Zimbabwe
}

\section{Author: \\ Joel Marashe ${ }^{1}$ \\ Affiliation: \\ ${ }^{1}$ Department of Old \\ Testament, University of \\ Pretoria, South Africa \\ Correspondence to \\ Joel Marashe \\ Email: \\ jg.marashe@yahoo.co.uk}

Postal address:

University of Pretoria, Faculty of Theology, Lynwood Road, Hatfield Campus, Pretoria 0002, South Africa

Dates:

Received: 20 May 2013 Accepted: 28 Nov. 2013

Published: 02 June 2014

How to cite this article: Marashe, J., 2014, 'The African traditional religious landscape: An examination of the role of traditional leaders in the fight against HIV and AIDS in Chipinge, Zimbabwe', Verbum et Ecclesia 35(1), Art. \#871, 8 pages. http://dx.doi. org/10.4102/ve.v35i1.871

Note:

The study presented here is based on research for my PhD: 'An examination of Shona traditional beliefs and practices in light of HIV and AIDS and its ramifications for mitigation and care' promoted by Professors A. Groenewald and H.J.C. Pieterse in the Faculty of Theology at the University of Pretoria. I gratefully acknowledge the research bursary I received from the University's Postgraduate Research Support that enabled me to conduct the research in the Chipinge district in Zimbabwe between October 2011 and July 2012.

\section{Read online:}

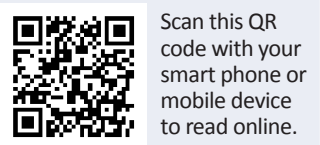

This study examines the role of traditional leaders, as custodians of culture, in the fight against infection with the HI virus and the AIDS pandemic in the Chipinge District of Zimbabwe. The research aims to assess traditional leaders' knowledge of HIV and AIDS and its causes. It also examines some traditional practices to determine whether they expose people to HIV and AIDS, and it evaluates the traditional leaders' roles in curbing the pandemic. From a phenomenological standpoint - and grounded in the African traditional religious landscape the study uses a survey research design. A convenient sample of 18 participants for the study consisted of 3 chiefs and 5 headmen who completed a questionnaire as well as 5 village heads and 5 elders who were interviewed and involved in four focus-group discussions (FGDs) that provided a variety of insightful information. The study identifies promiscuity as a major cause of HIV infection in communities. The results show that traditional leaders discourage barika and kuputsa as being harmful traditional marriage practices. Furthermore, the study indicates that traditional leaders encourage behavioural change amongst the youth and adults alike to curb the spread of HIV and that the pandemic could possibly be contained if government fully empowered the traditional leaders. The research has value in attempting to minimise the spread of HIV if communities discontinue harmful cultural practices. Therefore, donor agencies involved in intervention projects concerning the HIV and AIDS pandemic and government should work closely with traditional leaders who wield considerable power in areas under their jurisdiction to arrest the spread of the HIV and AIDS pandemic in the Chipinge district in Zimbabwe.

\section{Introduction}

African Traditional Religion (ATR) is the faith of indigenous African people, and the majority of communities in Africa south of the Sahara desert practise it whilst Islam is the dominant religion in North Africa. ATR encompasses ancestral and cultural traditions, writings, history, personal faith and religious experiences, transmitted orally from one generation to the next by the forebears of the present generation (Awolalu 1976:275). ATR is premised on beliefs and practices derived from the faith of ancient indigenous people - the ancestors (Bourdillon 1973:11). It is a way of life that permeates all spheres of everyday life, and unlike Christianity or Islam, ATR has no written literature and no specific founder (Awolalu 1976:2; Marashe, Ndamba \& Chireshe 2009:44; Thorpe 1991:1).

Traditional leaders function as religious leaders in their communities. From a traditional religious perspective, the study aims to examine the interface between traditional leaders, functionaries in traditional religion and a contemporary health challenge - the Human Immunodeficiency Virus (HIV) and the Acquired Immunodeficiency Syndrome (AIDS). It seeks to examine how traditional leaders in the Chipinge district of Zimbabwe perceive the HIV and AIDS scourge and to reveal their role in the prevention of new HIV infections and the spread of the pandemic in areas under their jurisdiction. Since the first confirmed case of AIDS in Zimbabwe in 1985 (Joint United Nations Programme on HIV and AIDS [UNAIDS] 2005), as Campbell (2010:1637) notes, efforts to prevent further infection were the target of political leadership, and they side-lined traditional leaders who have a great influence in the communities under their jurisdiction. This study claims that, perhaps, there are traditional practices that fuel the transmission of the HI virus and, thereby, harm the practitioners that they are supposed to protect.

In related studies, Duffy (2005:26) and Airhihenbuwa and DeWitt (2004:5) suggest that the people in Chipinge religiously hold on to their belief in the capriciousness of ancestral spirits and the nocturnal activities of witches. Their studies also show that, because of their socialisation, women 
are not able to discuss safe sex with their partners - let alone ask them to wear a condom during sex as men regard it as unAfrican. Requests for using condoms often lead to the beating of spouses because condoms are associated with prostitutes. This lack of openness and discussion in relationships renders women vulnerable and exposed to infection with the HIV virus.

The study by Airhihenbuwa and DeWitt (2004:5) shows that culture is cardinal to the health of communities, in general, and to individuals within those communities, in particular. They argue that culture is the bedrock on which people build their views of health matters, including HIV, and through which people elucidate and comprehend health issues that affect them. They concede that some traditional practices have been hit hardest by the impact of HIV and therefore lost their 'traditional mechanism for addressing health issues'. Also, in their view, the failure to come up with new traditional mechanisms to address health issues like HIV is traditional regression. Their study suggests that diverse stakeholders in the community could strengthen or reject behavioural change that takes place in the context of cultural traditions.

From a regional standpoint, a South-African case study by Campbell in 2010 concerning the role of chiefs in combating the HIV and AIDS pandemic shows that traditional chiefs underscore culture as the cradle of 'social cohesion in an uncertain social world'. On the issue of whether polygamy causes infection with the HI virus, one chief retorted, 'If I am faithful to all my wives and they are all faithful to me, who is going to infect any of us with HIV?' (Campbell 2010:1639). The study also indicates that the chief discourages the use of condoms and encourages people to protect themselves from infection by 'good behaviour'. He is also a strong proponent of virginity testing as a weapon against new HIV infections.

Whilst recently exploring a similar topic, the Southern Africa HIV and AIDS Dissemination Service (SAFAIDS) hosted a 5-day conference with chiefs and several stakeholders from the region and abroad..$^{1}$ The aim of the conference was to determine 'traditional practice, and its role in HIV and gender-based violence epidemics' as well as to explore ways to empower traditional leaders in the fight against HIV and AIDS and gender-based violence in their communities. The participants argued that culture is ever changing and intricate. They highlighted the importance of determining the negative aspects of culture that fuel the HIV and AIDS pandemic, and they reflected on whether the problem lies with actual practice or whether it is due to the abuse of community members. This observation is the central concern of this article. As pointed out in the preceding paragraphs, most studies have shown that culture plays a role in the spread of HIV and AIDS, but none has singled out traditional practices or cultural elements that they deem to be harmful in this regard. This study attempts to fill that gap.

1.SAFAIDS hosted a conference from 14 to 18 May 2012. Participants came from South Africa, Malawi, Tanzania, Togo, USA, Zambia and Zimbabwe. The topic for discussion was 'The role of traditional leaders in the prevention of HIV and gender-based violence'. More details are available at www.hivsharespace.net/node/87.
This study was conducted against a backdrop of serious statistics concerning HIV infection and the AIDS pandemic in sub-Saharan Africa, in general, and Zimbabwe, in particular. Simmons (2012:3) points out that, by 2007, the world had 33 million people living with the HIV or AIDS, and $67 \%$ of them lived in sub-Saharan Africa. According to Simmons (2012), the statistics about Zimbabwe are more frightening it is estimated that one in every five adults (or four in some publications) is infected, thereby catapulting the country into a position as one of the worst affected countries in Africa (National Aids Council [NAC] \& Ministry of Health and Child Welfare [MoHCW] 2004:14; Taylor 2007:232; Simmons 2012:3). The pandemic is so severe that it has significantly lowered the life expectancy of males to 37 years, from 60 years in 1990, and that of females to 34 years (Simmons 2012:3). He further maintains that Zimbabwe's economically productive age group (20-49 years) was hardest hit compared to other age groups. It is important to note that very little has been written on the Chipinge district per se but that there is an abundance of literature that focuses on the state of HIV transmission and the AIDS pandemic nationally, including urban areas like Harare (Simmons 2012:3). Therefore, this study intended finding out more about the state of HIV infection and AIDS in the remote and impoverished district of Chipinge. Before delving into that, however, a succinct description of the research area is provided below.

\section{A description of the Chipinge district}

The Chipinge district is $5296 \mathrm{~km}^{2}(1.4 \%$ of the total area of Zimbabwe) and is located in the southern part of the Eastern Highlands in Manicaland Province in Zimbabwe. Thomas Moodie established the town as a trading post in 1892 (see note 14 in Taylor 2007:229). According to the preliminary report on the 2012 national census, Chipinge district is home to approximately 326467 people (2.5\% of the total population of Zimbabwe) of whom 25675 live in Chipinge Town (Dzinotizei 2012:15). To the north of Chipinge is the Chimanimani district. The Chiredzi district is to the southwest, the Buhera district to the north-west and the Bikita district to the west.

The area is replete with fertile soil suitable for commercial farming. It is situated between the 'Chimanimani mountain range and a heavily forested plateau' in the east and the basalt soil of the low-veld (Taylor 2007:228). The eastern side of the district is very good for commercial farming because of its red soil's good capacity to retain water and the high level of rainfall. The Tanganda Tea Company is the largest, and one of the most successful multinational companies in Chipinge. It owns vast tracks of macadamia, avocado, coffee and tea estates such as Jersey, Zona, Ratelshoek, New Years' Gift and Clear Water. The undulating slopes ensure the good drainage of excess water and are carpeted with pine and wattle tree plantations that punctuate the terrain in the eastern part of the district that becomes flat as one moves to the semi-arid low-veld in the west. 
With regard to traditional leadership, the Chipinge district falls under the jurisdiction of seven chiefs, namely Mpungu, Garahwa, Mahenye, Musikavanhu, Mutema, Mapungwana and Gwenzi. It is worth noting that the position of chieftain - which dates back several centuries - is the fulcrum of the Ndau culture. Chiefs are sacred and immune to modern day democratic forces. They are sacred because they are associated with the origins of the particular communities they rule. They are immune to the democratic processes as they are not voted into the esteemed traditional offices but inherit their positions from their predecessors (Beall, Mkhize \& Vawda 2005:760; Miller \& Skinner 1968:188). Their sanctity imbues them with the power to rule their subjects.

However, the Zimbabwean government - like other emerging democracies in Africa - passed the Traditional Leaders Act (2000), Chapter 29:17, to regulate the activities of all traditional leaders. It spells out in detail the duties of chiefs, headmen and village heads. ${ }^{2}$ For instance, in Chapter 29:17, Part II, Section 5(b), the chiefs are given the power to promote and uphold cultural values and preserve the institution of the extended family as well as to promote traditional family life. Furthermore, the issue of land is fundamental to the chiefs' powers; it is a resource from which about 300792 people of Chipinge's rural populace obtain food (Dzinotizei 2012:15). The chiefs hold the power not only to allocate or withhold land but also to mediate in local disputes between members of the community under their jurisdiction (Campbell 2010, citing Ntsebeza 2006). As the 'custodians of tradition', the chiefs wield power and authority and are revered by all and sundry, particularly the elderly in the community (Campbell 2010:1638).

\section{Objectives of the study}

The intentions of this study were to:

- assess the extent to which traditional leaders use their influence to minimise the spread of the HIV and AIDS pandemic in their communities

- ascertain the traditional leaders' level of knowledge about HIV and AIDS, including its causes

- examine some of the traditional marriage practices with a view to establishing whether they, in fact, did not fuel the spread of HIV and AIDS.

\section{Theoretical framework}

Sociological and phenomenological theories inform this study. The sociological theory is convenient as it is concerned with describing and explaining social behaviour, social structure and interaction in relation to the environment (Haralambos, Holborn \& Heald 2004). It is a suitable approach for this research, which endeavours to comprehend the role of traditional leaders in the fight against infection with the HI virus, examine how they care for people with AIDS and assess some traditional marriage practices with a view to determining whether they fuel the transmission of HIV amongst the Ndau people of Chipinge.

2.Traditional Leaders Act, Chapter 29:17, especially Part II, Section 5; Part III, Section 9, and Part IV, Section 12, list the duties of all traditional leadership structures. The Act came into effect on 01 January 2000.
Phenomenological theory is significant because it is concerned with seeing a phenomenon, behaviour or religion as its adherents see it. In fact, the theory provides a means for investigating the way people come to know reality (Cox 1992:15). Through the process of epoche, I gathered qualitative data for the study after overcoming value judgments and preconceived notions about the beliefs and practices of the Ndau people of the Chipinge district (Chitando 1998). By using this theory, I suspended verdicts concerning the truth, value or validity of the phenomenon being studied. This is important because the findings mirror how traditional leaders perceive their world and how they are responding to HIV infections and the AIDS pandemic. Thus, traditional leaders' understanding of the transmission of the HI virus and AIDS in the areas under their jurisdiction and traditional marriage practices were studied sui generis. In terms of its application, the strength of the phenomenological theory is its ability to differentiate between the noumena [things as they are] and the phenomena [things as they are perceived] (Cox 1992:15). These theories are, thus, advantageous in that they elicited first-hand information from participants, particularly when used in conjunction with questionnaires and buttressed by semi-structured interviews - as was the case in this study (Fraenkel \& Wallen 1996:447).

\section{Methodology}

The population of the study consisted of the traditional leaders of the Chipinge district in Zimbabwe whose ages ranged from 40 to 56 . Traditional leaders and their immediate associates - headmen, village heads, chiefs' police and elderly men - were the key research participants in this study. The latter were selected based on their consistent involvement in the proceedings at the chief's dare [court]. Maturity and their knowledge of the traditional practices of the people were fundamental in identifying participants for the study. Therefore, the participants were purposefully sampled.

I used questionnaires and semi-structured interviews to gather qualitative data for this study. These research instruments were used to determine the traditional leadership's knowledge of HIV and AIDS, to gain insight into some of the traditional marriage practices that are perhaps assumed to fuel the spread of HIV and to assess the prevalence of the disease in the Chipinge district. Semistructured interviews were used because they enabled me to gather information about the interviewees' comprehension of the topics under investigation, and it allowed me to interpret the described phenomena well (Petersen 2009:3). By using the semi-structured interview, I had the advantage of probing for further clarification on unclear issues.

In addition, I conducted the interviews in the Ndau language so that all participants could understand the questions in order to provide sensible responses. It is through language that participants reveal their culture, beliefs and attitudes (Duffy 2005:25; Nyoni, Marashe \& Nyoni 2011:281). The interviews were audiotaped with the consent of the participants, ${ }^{3}$ and two experienced Shona language experts translated them into English.

3.Participants received and signed a copy of a consent form, explaining the objectives, benefits and dangers of taking part in the study. It included my responsibilities. 
I also presided over four focus-group discussions (FGDs) to buttress data from both the questionnaires and the interviews, which - as is shown below - provided rich and diverse data. The questionnaire had nine open-ended and six closed-ended questions. The latter provided a greater uniformity of responses that were easy to process whilst the former allowed participants to express their opinions freely. Questions concerning demographic data formed part of the closed-ended questions. These were important as they showed who were participating in the study and ensured the relevance of their responses. Field-notes and personal communication with participants were recorded in a diary.

The advantage of using these data-gathering tools is that they unveiled data of the phenomena under study 'in sufficient detail so that one who has not experienced it can understand it' (emphasis added) (Nyoni et al. 2011:280 citing Ary, Jacobs \& Razaciek 1990). In addition, I examined relevant literature pertaining to traditional leaders and the traditional practices and beliefs of the Ndau people. The Department of Traditional Leaders in the Ministry of Local Government, Urban and Rural Development provided the much-needed information about the current chiefs and the latest Traditional Leaders Act.

I conducted an analysis of the data by repeatedly listening to the recorded interviews with the aim of identifying codes, themes and topics for discussion. Additional themes were deduced from both the interview guide and the questionnaire. The data-set that contains demographic information; traditional leaders' opinions on the prevalence of the AIDS scourge; traditional marriage practices, like barika [polygamy] and kuputsa [pledged or forced marriages] and their knowledge of the major causes of the transmission of the $\mathrm{HI}$ virus in their communities is cardinal to the 'findings and discussion' section where it informs rallying points for discussion.

\section{Findings and discussion}

This section concurrently reveals the findings of the study and provides a discussion of these.

\section{Demographic data}

All the participants in the study were males. This is probably because traditional leadership positions are mostly - until in the new millennium - a preserve of the male members of the community. Traditional leadership has been male-dominated from time immemorial, and the status quo remains intact in the Chipinge district. This situation may be a consequence of the socialisation of children in African rural societies. Rusere (2011) aptly summarises the situation in the following quotation:

It is not by design that women find themselves in such marginalised areas of everyday lives but the African society has socialised them into believing that they are subordinated to their male counterparts. (p. 1)
However, there are now female chiefs in some parts of Zimbabwe's Matabeleland South and Mashonaland East provinces (Mpofu 2008). This is diametrically opposed to the widely held traditional principle of male primogeniture. In Zimbabwe, there are 268 chiefs of which 5 are women, and 4 out of 474 headmen are women which suggests 'a slight appreciation of the dynamic nature of culture' (Rusere 2011). ${ }^{4}$

Furthermore, traditional leaders in Chipinge are the elderly in society. Most of the interviewees were above the 50 years of age whilst the rest were around 40 years of age. This indicates that traditional leadership is the office of those who have seen it all, as it were. It belongs to those who can use their life experience to advise others and to discharge their duties and to those who have - over the years - learnt the traditions of the people they lead. This aspect was quite significant in a study that sought information concerning traditional practices of the people that the elderly could answer best.

Whilst all participants were married, the most interesting finding concerning this aspect is that there seemed to be a shift in marriage preferences. In the past, chiefs valued and married many wives and fathered many children. This has changed as only a few respondents were in polygamous marriages whilst the rest were in monogamous marriages. This is a positive development in the fight against infection with the HI virus and the AIDS pandemic, namely leading by example.

In terms of religion, the study reveals that the majority practise ATR whilst only a few are Christians. The fact that the majority of the participants practised ATR is important for this study, which is premised on the Ndau traditional beliefs and practices in light of the HIV and AIDS scourge. As traditional leaders are the principal religious functionaries in ATR, the study examined some traditional practices related to their role in the transmission of HIV.

The study shows that all participants were literate, the majority attended school up to Standard 6, some up to Secondary school level and one of them had a degree. That participants were literate is significant, their social status was high and - for the study - they were able to read, understand and complete (though slowly) the questionnaires given to them.

Of all the participants in the study, the majority were gainfully employed. Others were entrepreneurs or engaged in some form of work whilst only a few were unemployed. For the study, this meant that it was difficult to find time to engage with them in the research, as I had to fit in with their tight schedules. Weekends were their busiest time. Often they would be presiding over traditional courts dealing with various issues in their communities. In a few instances, they were quite free to attend sessions for this research. The 4. In an article entitled 'Africa's women grab fair share in leadership', Rusere (2011) shows how African women are faring not only in political leadership positions but also in traditional positions as well. Further details are on www.africanews.com/ site/list_message/3. 
economic status of the participants was, therefore, good for the study, and they willingly participated without expecting any remuneration. It may be questioned that providing data out of a genuine willingness to share an opinion imbues it with unparalleled credibility when compared to data given on a basis of what one gets out of it or to please the researcher.

This section has shown that traditional leadership in the Chipinge district is predominately patriarchal and involves elderly men in the society even though there are now female chiefs and headwomen in some of the provinces of the country. Most respondents are monogamously married but a few are still polygamous. This shift in marriage patterns by the elderly in society sends a strong message in the fight against infection with the HI virus. Sticking to one faithful marriage partner keeps one safe from infection, and there could be no better way to spread the message to the youth than for the elders to be exemplary in their conduct and their marriages. The fact that all participants had completed school - albeit at different levels - meant that they were able to read and complete the questionnaires, which for purposes of getting the message across and understood were translated into the Ndau language. The majority of respondents still practice ATR, which renders further value to this study as the Shona traditional practices are the bedrock of this study, especially when viewed through the lens of the AIDS pandemic. Above all, the demographic information, especially the socioeconomic status (SES) of the participants, was helpful in the study. It ensured that the right participants participated and that the data collected was in and from the proper context.

\section{Perceptions regarding the prevalence of HIV and AIDS}

The following questions were asked to obtain information about participants' knowledge of the transmission of the $\mathrm{HI}$ virus, the AIDS pandemic and some Shona traditional marriage practices.

\section{How prevalent is the HIV and AIDS pandemic in your area of jurisdiction?}

The majority of the participants indicated that the prevalence of infection with the HI virus and the resultant AIDS in the Chipinge district is decreasing. The FGDs corroborated this outcome. Most participants expressed the view that the pandemic has declined in most areas. They also argued that the areas where the disease is still prevalent are those that skirt business centres or growth points - places replete with pubs and nightclubs. Furthermore, students in secondary school are able to access alcohol directly from the bottle-stores without any problems since no one enforces the restriction not to sell liquor to those who are under-age (18 years). Some bottle-store owners even have the audacity to hide truant students from school authorities in their back-yard rooms.

\section{What do you think are the major causes of HIV and AIDS in your area?}

The traditional leadership in the Chipinge district identified the sexual promiscuity of those who were single and widowed as well as unfaithfulness in marriages as the major drivers of HIV infections and the AIDS pandemic. In the FGDs, a few participants pointed to unprotected sex as a major cause of infection. They identified the proliferation of beer-halls in business centres such as Mundanda, Chako, Tamandai, Tanganda Halt, Chibuwe, Checheche and Chisumbaje and the high consumption of chikeke [locally brewed beer the alcohol content of which is unknown] as some of the causes of the spread of the HI virus. The situation becomes worse when considered in conjunction with the point highlighted above concerning the free access that secondary-school students have to alcohol at beer halls. Participants argued that, when drunk, people forget their morals and indulge more freely in immoral activities, including sexual promiscuity. Therefore, according to the traditional leaders' perceptions, alcohol abuse and drunkenness are responsible for promiscuity that may subsequently lead to infection with the HI virus. It was apparent during the FGDs that the participants viewed alcohol abuse or drunkenness as one of the main reasons for unfaithfulness in marriage and in relationships in general. Their argument was premised on the assumption that, once people get drunk, they are bound to cheat on their spouses or sexual partners - irrespective of whether they are married or simply dating. According to one participant, 'Kana vadakwa vanonga vaanechidengu, zvekuti vanonga vooti chero wevaona votoata naye. ${ }^{5}$ [When drunk, they will have high libido, such that they will want to have sex with anyone.]

Another aspect of unfaithfulness pointed to by the FGDs is that of extra-marital affairs. Probed to explain why this was a serious issue in the community, participants cited working in South Africa as a contributory factor: 'maJoni-joni' anosiya vakadzi uneno, vopetuke Joni kwaakuriyarwa kuti vakasiye vakadzi. Ngendaa yenzara yevamuna, vakadzi vanopedzisira voohura nevamuna, vamweni vacho vatori nemizi yavo. ${ }^{7}$ [The young men work in South Africa and leave their wives behind when they go back to work and stay away for a long time without coming home, forgetting that they left their wives. Because of the desire for a husband, the wives end up having sexual relations with men - some of whom have their own families.]

At face value, the issue of extra-marital affairs should not be a problem. However, with the AIDS scourge wreaking havoc in society and sparing no one, it may be justified to suggest that extra-marital affairs are a recipe for disaster. With the women's lack of ability to compel the use of condoms during sex, they are vulnerable and at risk of infection. Thus, they risk contracting not only sexual transmitted infections (STIs) but also the HI virus, which they pass on to their unsuspecting husbands who only come home from South Africa once a year - if they come at all. Alternatively, because of their long stay away from home, the men may also engage in extramarital affairs and contract STIs or the HI virus, which they pass on to their unsuspecting wives when they take a break from their workplace and go back home, especially during the Easter holidays or the annual shut-down in December.

5.Fieldwork diary notes at Headman Chindezwa's court in Muzite village which falls under Chief Gwenzi's jurisdiction, 15 January 2012.

6.Joni is a term that refers to South Africa and maJoni-joni refers to young men who go to search of work in South Africa.

7.Fieldwork diary notes, 18 December 2011, at Headman Murenje's dare [court] in Chief Musikavanhu's chiefdom. 
Thus, whilst sexual promiscuity was ranked highly as a cause of infection with the HI virus, it is interesting to note that there are other peripheral causes, which if taken holistically, show the kinds of perceptions traditional leaders in the Chipinge district have of the causal factors of the transmission of the $\mathrm{HI}$ virus in the areas under their jurisdiction. In their view and for various reasons, chihure (sexual promiscuity) which comes from unfaithfulness in relationships (pre-marital) or as extra-marital affairs (post-marital) causes the transmission of the deadly HI virus. In addition, this is more frightening considering the fact that approximately $90 \%$ of HIV infections in Zimbabwe occur through heterosexual contact (Duffy 2005:23, quoting UNAIDS/ World Health Organization [WHO] 2002).

\section{Traditional Ndau marriage practices}

The following questions were asked to obtain information about the traditional marriage practices of the Ndau people.

\section{In light of HIV and AIDS, what is your opinion of barika}

The majority of the respondents indicated that barika [polygamy] is discouraged in most of the areas under study. The FGDs supported this as there was consensus when participants spoke boldly against barika. The most vocal participants in the FGDs were at Headman Munamba's homestead. They argued that, nowadays, life is too expensive to support a big family - let alone in a barika:

\begin{abstract}
'Kuroora vakadzi vakawanda kwonesa mazuwa ano. Chinonyanye kunesa isapoti ... madzimai nevana vanonga vechide chekurya, chekupfeka, kubhadhare mare yechikora yegurumwandira revana ... iii, azvichakoneki. Zvasiyana nekudhaya ngekuti kwainga kuchaibva, uye madzimai vaiendawo kooshanda kwaTondoro kana kuJersey. ${ }^{\prime 9}$ [Marrying many wives is problematic nowadays. The greatest problem is support ... wives and children need food, clothing, and paying school fees for a team of children ... mmm, it is no longer possible. It is different from the past when there used to be plentiful harvest and women going to work at Tondoro [nickname for Smalldel Coffee Estate] or Jersey Tea Estate.]
\end{abstract}

This seems to suggest that the discontinuation of polygamy is due to circumstances such as poverty, perennial low rainfall patterns leading to poor harvests and the high cost of living rather than the people's choice. Therefore, the study reveals that cases of polygamy - as a marriage type - are becoming less popular for a variety of reasons, which may include men's fear of contracting HIV and developing AIDS. Another form of traditional marriage practice is kuputsa [pledged or forced marriage] that is dealt with in the next sub-section.

\section{In light of HIV and AIDS, what is your comment on kuputsa [pledged or forced marriages]?}

Most of the traditional leaders who participated in the study were unanimous in their views that the practice of kuputsa has decreased significantly in areas under their control whilst a few maintain that kuputsa is still practised. During 8.Barika is a Shona term referring to polygamy.

9.Fieldwork diary notes at Headman Munamba's homestead which falls in Chief Gwenzi's chiefdom, 23 January 2011. the FGDs, participants voiced their concern about the trauma that the girl-child suffers when pledged for or even forced into marriage without her consent. The argument made was that the practice is not only outdated but is also against children's rights as enshrined in the Africa Charter on the rights and welfare of the child (1999) ${ }^{10}$ and that the practice is discouraged by the government. At Murenje village to the southeast of the Chikore Mission, Headman Murenje pointed out: 'Iyi tsika aichanyanywi kuitwa mundau munomu, chezvinoita ngechekuti, dai yechinyaitwa, inoitwe muchihware-hware ngekuti Mambo Musikavanhu wakambaaronza kuti Hurumende aizvidi, uye kuti unonga abatwa unosungwa.'11 [This practice is no longer practised in this area; however, even if it is still done, it is done clandestinely because Chief Musikavanhu announced that the government is against it, and whoever is caught practising it will be arrested.]

In Tauya village in Dzika to the west of the Chikore Mission, a headman under the chieftaincy of Musikavanhu concurred with Headman Murenje by stating that kuputsa could be practised if it was done to save the lives of family members who were under a spell of ngozi [the avenging spirits] (M. Mbonyeya [Headman] pers. comm., 05 February 2012). ${ }^{12}$ In such circumstances, the young and innocent girl - used to appease the avenging spirit - becomes a homicide bride and a sacrificial lamb for the survival of her family. ${ }^{13}$ The danger of such a practice is that the benefactor, namely the husband, will force the young girl to have sexual intercourse before she is mature enough, and it exposes her to STIs or the deadly HIV infection. She is too young to either consent or negotiate safe sex. The girl-child is coerced into marriage and is susceptible to abuse and exploitation by her spouse (Monyane 2013:70). Whilst it is difficult to correlate kuzvarira with the prevalence of HIV in the Chipinge district, qualitative data from the sample - in conjunction with information from the FGDs seems to suggest that, although the practice is declining, it carries a high risk of infection.

\section{Traditional leaders' role in combating the spread of HIV and AIDS}

The following question was asked to establish the traditional leaders' roles in combating the spread of HIV and the AIDS scourge.

10.African Charter on the Rights and Welfare of the Child, Chapter 1, Article 1 and Subsection 3 (African Union 1999), amongst others, discourages traditiona and Subsection 3 (Africanistent with the Charter and Article 16 discouraditional practices that are inconsistent with the Charter and Article 16 discourages both physical and sexual abuse of children. OAU Doc. CAB/LEG/24.9/49 was enforced on 29 November 1999. More details at: www.au.int/en/sites/default/files/Charter En_African_Charter_on_the_Rights_and_Wlefare_of_the_Child_AddisAbaba_ July1990.pdf.

11.Fieldwork diary notes at Headman Murenje's court in Chief Musikavanhu's jurisdiction on 19 December 2011.

12.Ngozi as the spirit of a person who died with a grudge over a grave injustice suffered during his life or that of a murdered stranger. The attack by ngozi is unpredictable and perilous. It often leads to a series of deaths in quick succession in the family of the one responsible for murder and the remedy is to appease the spirit (Bourdillon 1976:183; Mutekwa 2010:163). The United Nations Children's Fund (UNICEF) (2000:134) reported on an instance in Chiredzi in the south-eastern low-veld of Zimbabwe where' $\mathrm{girl}$ was sold for ZW\$1500 to a person who needed a girl for a family he had wronged to make peace with vengeful (ngozi) spirits'.

13.Young girls are married to wealthy men to avert starvation, especially in times of a perennial poor harvest. The practice mushroomed in other districts too. For instance, in Nyamajura to the east of Harare, a girl of 14 was married to a 65-year instance, in Nyamajura to the east of Harare, a girl of 14 was married to a $65-y e a r$
old geriatric to save the family from starvation. More details at: http://mg.co.za/ article/2006-05-17-hunger-forces-zim-girls-into-forced-marriages. 


\section{As custodians of culture, what do you encourage your community to do to avoid HIV and AIDS?}

The study shows that the majority of traditional leaders encourage their communities to change their behaviour in order to win the battle against infection with the HI virus and other STIs. What was clear from the FGDs is that encouraging safe sex using condoms had its problems, including a lack of knowledge on how to wear them and being misconstrued as encouraging sexual indulgence amongst the youth. Furthermore, the FGDs vehemently recommended the following: '... kudzibata mukurumba, ndookuti chirwere cheshuramatongo chiite chishomani. Vabude muzera vasasaamba ekuroorana vasikazi koozemenwa ngazi veshe.' ${ }^{14}$ [Avoiding prostitution reduces the spread of AIDS. Those who want to get married should first have a blood test.]

The traditional leaders pointed out that they often take advantage of crowds that are present at agricultural field days, traditional court sessions or receiving food aid to warn them of the dangers of HIV and to encourage them to be faithful to their spouses or sexual partners. The leaders encourage the youth to refrain from any sexual activity before marriage and to use condoms if they are unable to abstain or control themselves.

Furthermore, Chief Mapungwana indicated that, using his government-donated vehicle, he personally drives rape victims in his community to the hospital as soon as he receives a report of the crime so that the victim can receive medical treatment immediately (pers. comm., 04 March 2012). ${ }^{15} \mathrm{He}$ subsequently ensures that his 'policemen' arrest the culprit with the assistance of the whole community before handing him over to the state police for incarceration.

In terms of the same issue, before sending the culprit to the police, a headman of Chibuwe village orders him to pay reparation in the form of 'mwombe nemwana wayo' [two head of cattle] to the family of the victim (Headman Mutorwa, pers. comm., 18 March 2012). ${ }^{16}$ The full wrath of traditional law is also unleashed on men who engage in extra-marital affairs. They pay the same compensation to the offended party. The headman argued that these measures are a deterrent to would-be offenders because their families then ensure that the youths and the men are careful in what they do as mwombe nemwana wayo is beyond the reach of many in these remote, rural and impoverished communities.

Thus, the study shows that by being vigilant, assisting sexually abused victims and enlisting the help of or helping the state police to minimise sexually related crime and by encouraging abstinence and safe sex, traditional leaders are supporting their communities in minimising the spread of the HIV pandemic.

14.Fieldwork diary notes at Headman Mupfudze's homestead which falls under Chief Mapungwana's jurisdiction, 29 February 2012

15.Interview with Chief Mapungwana at his homestead near the Mt. Selinda Mission, 04 March 2012.

16.Chibuwe village falls under the jurisdiction of Chief Musikavanhu.

\section{Conclusion and recommendations}

Traditional leaders are the custodians of their communities' culture and, thus, are strongly positioned to influence a cultural revolution to minimise the spread of HIV and AIDS. With their power legitimised by the communities from which they come and by the Traditional Leaders Act, traditional leaders in the Chipinge district have all the power it takes to play a positive role in the fight against infection with the HI virus.

The study aimed to show how traditional leaders use their influence in minimising the spread of HIV and to examine the impact of some traditional marriage practices in the spread of the pandemic. It also aimed to determine the leaders' comprehension of the causes of HIV transmission and to establish the prevalence of the scourge in the communities under their jurisdiction.

Sociological and the phenomenological approaches informed this study. Whilst the sociological approach is concerned with explaining social behaviour and interaction, the phenomenological method contributes by suspending value judgements about the issues being studied. The result is that, as the researcher, I saw and experienced the issues raised in the same way as the participants perceived and experienced them.

Eighteen subjects participated in the study. They completed a questionnaire that had both open-ended and closed-ended questions. Due to the limitation of time, eight semi-structured interviews were conducted and audio-recorded. Four FGDs were conducted to supplement data from questionnaires and interviews, these yielded valuable data.

The study found that the prevalence of the transmission of the HI virus has decreased, possibly because of the chiefs' decrees to stop harmful traditional practices such as kuputsa and barika. As a result, there has been a decline in these marriage practices, but there is still a danger in the clandestine nature of kuputsa. It is worth noting that the majority of the participants are, in fact, in monogamous marriages - a situation which is diametrically different from that of the past where it was the norm for men, in general, and chiefs, in particular, to marry many wives. The study has shown that traditional leaders perceive promiscuity as one of the chief causes of HIV and AIDS - exacerbated by lust after imbibing alcohol. The chiefs strongly encourage behavioural change, especially amongst the youth, by exhorting them to delay engaging in sexual activities until after marriage. If the men cannot control their sexual urges, then the chiefs urge them to practice safe sex by wearing condoms. This view might be a sound explanation for the decline in the prevalence of HIV and AIDS cases in the Chipinge district. Therefore, the study recommends that government and donor agencies working on HIV and AIDS intervention programmes in the district should, adequately, capacitate traditional leaders, thereby enabling them to curb the spread of the pandemic. Furthermore, there should be further research into other specific traditional practices 
to determine which are harmful to the community and to find ways to modify them for the safety of the people - to discourage them or at best to discontinue them.

\section{Acknowledgements}

I would like to thank my study promoters, Professor A. Groenewald and Professor H.J.C. Pieterse, for their assistance in drafting the research study proposal which yielded the data of which this article is only a segment. I also want to thank the University of Pretoria, particularly the Faculty of Theology, for giving me a cover letter clearing me to carry out research in the Chipinge District in Zimbabwe. Furthermore, I wish to thank the Ministry of Local Government, Urban and Rural Development for allowing me to do research on traditional leaders in Chipinge. My thanks go to Mr N. Mawomo, a staff member in the Department of Traditional Leaders in same ministry, for assisting me both with information on traditional leaders in Zimbabwe and the Traditional Leaders Act; it certainly made data easier to collect and collate.

\section{Competing interests}

The author declares that he has no financial or personal relationship(s) that may have inappropriately influenced him in writing this article.

\section{References}

African Union, 1999, 'African charter on the rights and welfare the child', viewed 15 April 2013, from http://www.au.int/en/sites/default/files/Charter_En_African Charter_on_the_Rights_and_Wlefare_of_the_Child_AddisAbaba_July1990.pdf

Airhihenbuwa, C.O. \& DeWitt, J.W., 2004, 'Culture and African contexts of HIV \& AIDS prevention, care and support', SAHARA-J: Journal of Social Aspects of HIV \& AIDS: An Open Access Journal 1, 4-13. http://dx.doi.org/10.1080/17290376.2004.9724 822, PMid:17600995

Awolalu, O., 1976, 'Sin and its removal in African traditional religion', Journal of the American Academy of Religion 44, 275-287. http://dx.doi.org/10.1093/jaarel/ XLIV.2.275

Beall, J., Mkhize, S. \& Vawda, S., 2005, 'Emergent democracy and "resurgent" tradition: Institutions, chieftaincy and transition in KwaZulu-Natal', Journal of Southern African Studies 31, 755-771. http://dx.doi.org/10.1080/03057070500370530

Bourdillon, M.F.C., 1973, 'Traditional religion in the Shona society', in J.A. Dachs (ed.), Christianity south of the Zambezi, vol 1, pp. 11-24, Mambo Press, Gwelo.

Bourdillon, M.F.C., 1976, Shona peoples: Ethnography of the contemporary Shona with special reference to their religion, Mambo Press, Gwelo.

Campbell, C, 2010, 'Political will, traditional leaders and the fight against HIV \& AIDS A South African case study', AIDS Care:Psychological and socio-medical aspects of AIDS/HIV 22, 1637-1643.
Chitando, E., 1998, 'The phenomenological method in a Zimbabwean context: To liberate or to oppress?', Zambezia 25, 99-114.

Cox, J.L., 1992, Expressing the sacred: A phenomenological approach, University of Zimbabwe Publications, Harare.

Duffy, L., 2005, 'Culture and context of HIV prevention in rural Zimbabwe: The influence of gender inequality', Journal of Transcultural Nursing 16, 23-31. http:// dx.doi.org/10.1177/1043659604270962, PMid:15608096

Dzinotizei, M., 2012, 'Census 2012 preliminary report', viewed 23 January 2012, from www.zimstat.co.zw/dmdocuments/CensusPreliminary2012.pdf

Fraenkel, R. \& Wallen, N.E., 1996, How to design and evaluate research in education, McGraw-Hill, New York.

Haralambos, M., Holborn, M. \& Heald, R., 2004, Sociology: Themes and perspectives, Collins, London.

Marashe, J., Ndamba, G.T. \& Chireshe, E., 2009, 'The teaching of African Traditional religion in primary schools in Zimbabwe: Challenges and opportunities', Religious Education 104, 38-50. http://dx.doi.org/10.1080/00344080802615325

Miller, N.N. \& Skinner, E.P., 1968, 'The political survival of traditional leadership: The "paradox" of rural leadership: A comment', The Journal of Modern African Studies 6, 183-201. http://dx.doi.org/10.1017/S0022278X00017146

Monyane, C., 2013, 'Is ukuthwala another form of “forced marriage"?', Journal of the South African Sociological Association 44, 64-82. http://dx.doi.org/10.1080/215 28586.2013.817050

Mpofu, S., 2008, 'Zimbabwe breaks new ground in traditional institutions', viewed 28 February 2013, from www.african.net/fs-38.htm

Mutekwa, A., 2010, 'The avenging spirit: Mapping an ambivalent spirituality in Zimbabwean literature in English', African Studies 69, 161-176. http://dx.doi. org $/ 10.1080 / 00020181003647264$

National AIDS Council (NAC) \& Ministry of Health and Child Welfare (MoHCW), 2004 'The HIV and AIDS Epidemic in Zimbabwe: Where are we now? Where are we going?', Government Publishers, Harare.

Nyoni, M., Marashe, J. \& Nyoni, T., 2011, 'The quest for inclusive education: The case of Pakame High School', Journal of Sustainable Development in Africa 13 278-294.

Petersen, M., 2009, 'Cultural practices, gender and HIV \& AIDS: A study of young women's sexual positioning in the context of HIV \& AIDS in South Africa', in J.B.A.A. Breidlid (ed.), HIV \& AIDS in Sub-Saharan Africa: Understanding the implications of culture and context, n.p., UCT Press, Cape Town.

Department of Traditional Leaders, 2000, Traditional Leaders Act, Chapter 29:17, Government Publishers, Harare.

Rusere, M., 2011, 'Africa's women grab fair share in leadership', Africa News.com, 27 October 2011

SAFAIDS, 2012, 'The role of traditional leaders in the prevention of HIV and genderbased violence', viewed 01 March 2013, from www.hivsharespace.net/node/87

Simmons, D.S., 2012, Modernizing medicine in Zimbabwe: HIV/AIDS and traditional healers, Vanderbilt University Press, Nashville.

Taylor, T.N., 2007, '“A place of trouble": The political ecology of HIV \& AIDS in Chipinge, Zimbabwe', Safundi-J: The Journal of South African and American Studies 8, 223256.

Thorpe, S.A., 1991, African traditional religions: An intrduction, University of South Africa, Pretoria.

Joint United Nations Programme on HIV and AIDS (UNAIDS), 2005, 'Evidence for HIV decline in Zimbabwe: A comprehensive review of the epidemiological data', viewed 20 July 2007, from http://www.search.unaids.org/Preview.aspx?=Publications/ zimbabwe_epi_report_nov05

The United Nations Children's Fund (UNICEF), 2000, We are also human beings: A guide to children's rights in Zimbabwe, Africa Community Publishing Trust, Harare. 